The Urban Aboriginal Middle-Income Group in Canada: A Demographic Profile

Amanda Parriag

Amanda Parriag and Associates

Paul Chaulk

Atlantic Evaluation Group Inc.

aboriginal policy studies Vol. 2, no. 2, 2013, pp.34-63

This article can be found at:

http://ejournals.library.ualberta.ca/index.php/aps/article/view/19005

ISSN: $1923-3299$

Article DOI: http://dx.doi.org/10.5663/aps.v2i2.19005

aboriginal policy studies is an online, peer-reviewed and multidisciplinary journal that publishes original, scholarly, and policy-relevant research on issues relevant to Métis, non-status Indians and urban Aboriginal people in Canada. For more information, please contact us at apsjournal@ualberta.ca or visit our website at www.ualberta.ca/nativestudies/aps/. 


\title{
The Urban Aboriginal Middle-Income Group in Canada: A Demographic Profile
}

\author{
Amanda Parriag \\ Amanda Parriag and Associates \\ Paul Chaulk \\ Atlantic Evaluation Group Inc.
}

\begin{abstract}
Recent research suggests that there is an emerging urban Aboriginal middle-income group in Canada but little is known about it. This article examines the demographic profile of the urban Aboriginal middle-income group (excluding First Nations living on-reserve) from the 2006 Aboriginal Peoples Survey in comparison to the non-Aboriginal population from the 2006 Census. Results showed that there is a definite urban Aboriginal middle-income group in Canada that is demographically similar in many ways to the non-Aboriginal middle-income group, with language the one variable where the pattern was completely different. Aboriginal people were more likely to be in the lower-income group and less likely to be in the higherincome group than non-Aboriginal people, while the proportion in the middle-income group was often similar. Among Aboriginal people, First Nations had lower income levels than other Aboriginal people, even at higher education levels.
\end{abstract}

\section{Introduction: A Snapshot of the Urban Aboriginal Population}

The Aboriginal ${ }^{1}$ population in Canada is becoming increasingly urbanized. In 2006, according to data from Statistics Canada, 54 percent of Aboriginal people in Canada lived in an urban centre-an increase of 50 percent from 1996. Of those living in an urban centre, 50 percent were First Nations, 43 percent were Métis, and relatively few were Inuit ${ }^{2}$ (Statistics Canada, 2008). Further, Norris and Clatworthy (2011), in their analysis of Canadian Census data, showed that the proportion of all Aboriginal people living in

1 The distinction between Aboriginal ancestry and Aboriginal identity is outlined in Statistics Canada (2007). In this Statistics Canada article, Aboriginal identity in the 2006 Census is described as using data from four questions focused on "ethnic origin (including Aboriginal ancestries), Aboriginal identity, Registered or Treaty Indian; and Member of an Indian Band or First Nation" (2007, 7). The article goes on to outline that there "is no single or "correct" definition of Aboriginal populations (7). The choice of a definition depends on the purpose for which the information is to be used. Different definitions are used depending on the focus and requirements of the user ..." The article explains that Aboriginal identity is "a person's affiliation with an Aboriginal group that is North American Indian, Métis or Inuit" (8). Note that "the 2001 and 2006 Aboriginal People Surveys covered both the Aboriginal identity and Aboriginal ancestry populations, while the 1991 APS focused on the Aboriginal identity population" (10) highlighting that the populations under examination are not the same.

2 Seven percent were Inuit and other Aboriginal people combined.

aboriginal policy studies, Vol. 2, no. 2, 2013

www.ualberta.ca/nativestudies/aps/

ISSN: 1923-3299 
urban areas had increased from 13 percent to 53 percent between 1961 and 2006. While the urbanization of Aboriginal people is an identified trend, surprisingly little is known about the makeup of this group and the research done so far has not clearly shown what impact urbanization has had on it. For example, in urban areas with substantial proportions of Aboriginal people, there has been a notable absence of Aboriginal-owned businesses, Aboriginal-focused organizations, or Aboriginal-specific services usually found in areas of ethnic concentration. There has been a concurrent absence of opposition to Aboriginal people in these areas, such as that found in some inner city neighbourhoods in US cities (Canada Mortgage and Housing Corporation 2008). Despite the fact that some research found that this group experiences much lower levels of income than reported in the Census (Smylie et al. 2011), and the assumptions that this would place on housing and standards of living, the urban Aboriginal population is portrayed in recent Environics' research as being content with their place of residence (Environics Institute 2010). However, there is a lack of deep understanding of the urban Aboriginal population beyond income disparities between Aboriginal and non-Aboriginal people and basic demographic characteristics. This is a huge gap in our knowledge base.

This article begins by outlining what is known about the urban Aboriginal population, particularly in the areas of geography, mobility, language, gender, age, and income. For example, we know that the proportion of Aboriginal people residing in urban areas varies significantly by province and territory, and that Aboriginal people tend to move more often than non-Aboriginal Canadians do. It appears that the numbers of Aboriginal people able to speak an Aboriginal language is lower in urban areas in comparison to non-urban areas, but gender and age distribution among urban Aboriginal people is not as well documented. While some newer research on urban Aboriginal people has pointed to an emerging urban Aboriginal middle-income group, much of the existing research has been limited to a focus on income disparities between Aboriginal and non-Aboriginal people and the issues that come with poverty among Aboriginal people.

\section{Geography}

In 2006, First Nations people made up 50 percent of the urban Aboriginal population across the country; 43 percent were Métis. Very few Inuit live in urban centres outside the North (Statistics Canada 2008). In Ontario, 70 percent of the largest proportion of Aboriginal people, First Nations people, lived off-reserve in 2006. By comparison, 77.2 percent of Aboriginal people in 2006 lived in urban areas off-reserve (Ontario Trillium Foundation 2011).

About 90 percent of the urban Aboriginal population of Canada resides in one of twelve cities: Winnipeg, Edmonton, Vancouver, Calgary, Toronto, Saskatoon, Ottawa-Gatineau, Montreal, Regina, Thunder Bay, Sudbury, and Hamilton (Norris and Clatworthy 2011). In terms of geographic location, Winnipeg has the highest proportion of urban Aboriginal people, making up 10 percent of the total city population. Saskatoon and Regina have 9 percent Aboriginal people and Edmonton has Aboriginal people comprising 5 percent of its population Vancouver, Toronto, and Calgary also have large numbers of Aboriginal people, but Aboriginal people make up less than 2 percent of the total urban population 
in these centres. In smaller urban centres; such as Thompson, MB, Prince Rupert, BC, and Prince Albert, SK; the numbers of Aboriginal people are smaller but Aboriginal people represent between 34 and 36 percent of the total urban population (Statistics Canada 2008, 13).

\section{Mobility}

The urban Aboriginal population is known to be more mobile that the urban nonAboriginal population ( 45 percent vs. 21 percent having moved within the same urban community between 1991 and 1996). There is also a wide variation in mobility among Aboriginal subgroups (Registered Indians, non-status Indians, Métis, and Inuit) and according to geography, as indicated by data from the 1996 Census and the 1991 Aboriginal Peoples Survey (APS) (Norris and Clatworthy 2003, 55-56). As a starting point, some research has found that, when Aboriginal people move to urban areas, they tend to settle there. In a recent national survey, 70 percent of first-generation urban Aboriginal people (i.e., Aboriginal people who were born and raised in another community, town, city, or reserve than the urban area they currently reside in) said that they have not moved back to their home community since moving to their current city of residence (Environics Institute 2010, 34). However, analysis of older Census data has uncovered findings that continue to raise questions, rather than give clear answers. Looking at trends in Census data, the conclusion we have drawn is that the increasing urbanization of Aboriginal people is not the result of a mass exodus from reserves to cities since there has also been an overall increase of populations on reserves. As well, research using Census data has found that people in recent years have declared their ethnicity ${ }^{3}$ in a different way than they might have previously (i.e., newly claiming their Métis or First Nations status for themselves and their children), which has contributed to the increased counts of urban Aboriginal people in the Census. Finally, a higher birth rate accounts for the faster growth of the Aboriginal population when compared to that of non-Aboriginal populations in urban areas (Guimond, Robitaille, and Senecal 2009; Norris and Clatworthy 2011). It is likely that increased urban Aboriginal populations are the result of a combination of these factors; clear answers are still not within reach.

Census data also suggests that First Nations who are Registered Indians under the Indian Act and who live off-reserve tend to move more often than the on-reserve population or the non-Aboriginal population. One analysis showed that 66 percent of offreserve First Nations who were Registered Indians had moved between 1991 and 1996; 29 percent moved between communities and 37 percent moved within the same community off-reserve. In the Canadian population, 43 percent had moved in the same time period (23 percent residential movers and 20 percent migrants) (Norris and Clatworthy 2003, 55).

3 Guimond (2003) examined the issue of ethnic mobility— "the phenomenon where individuals and families experience changes in their ethnicity" (42) due to a variety of factors, including propinquity between people with different ethno-cultural backgrounds in urban areas and the families and children that can result; and socio-political events that have restored pride in reclaiming one's Aboriginal heritage and policy decisions, such as the 10985 amendments to the Indian Act (44). As well, Guimond suggested that ethnic drifters may account for changes in socio-economic characteristics, such as education (45). 
In another study, 25 percent of the Aboriginal population in Manitoba said that they were likely to move in the next twelve months, with off-reserve First Nations (33\%) being most likely to say this (Adams 2009, 74).

The types of moves among Aboriginal people also vary by geographic area. In large cities, urban Métis people were most likely to move within the same community (70\%), followed by Registered Indians (65\%), non-Status Indians (62\%), non-Aboriginal people $(55 \%)$, and Inuit $(46 \%)$ (Norris and Clatworthy 2003, 56). In rural areas, by comparison, 83 percent of Inuit moved within the same community compared to 50 percent of all other Aboriginal people, and 40 percent of non-Aboriginal people. In many cases, frequent moves among Aboriginal people appear to be tied to poverty and the strictures that this situation places on finding a residence (Urban Aboriginal Task Force 2007).

\section{Language}

Aboriginal language is often perceived to be a large part of Aboriginal culture and the method by which culture and traditions are passed to other Aboriginal people through generations. Urban Aboriginal people place a great deal of importance on being able to speak an Aboriginal language, although this is not necessarily tied to the ability to do so. More than 90 percent of Aboriginal respondents (92.5\%) in one survey said it was important to speak an Aboriginal language, although only 50.5 percent said they were capable of doing so (Urban Aboriginal Task Force 2007, 83). It appears that the ability to speak an Aboriginal language is lower in urban areas in comparison to non-urban areas. In 1996, only 12 percent had the ability to converse in their language (Norris 2006, 203). By subgroup, in 2006, 12 percent of First Nations off-reserve and 51 percent of First Nations on-reserve could speak an Aboriginal language (Statistics Canada 2008, 48). Among Métis, 2 percent in urban areas could speak an Aboriginal language (Michif), as compared to 6 percent in rural areas (Statistics Canada 2008, 37). Only 15 percent of Inuit in urban areas spoke Inuktitut in 2006, while 84 percent of those in Inuit Nunangat could do so (Statistics Canada 2008, 28).

\section{Gender and Age}

The distribution of gender and age among urban Aboriginal people is not well documented. One recent survey noted an over-representation of Aboriginal women survey respondents in urban areas, but this is not necessarily indicative of greater actual proportions of Aboriginal women relative to Aboriginal men in urban centres across the country (Environics Institute 2010). As many other authors have done, the National Association of Friendship Centres estimates that the proportion of women in urban areas could be considered in the context of the proportion of Aboriginal people who are women (51\%) and the age of Aboriginal women overall (50\% under the age of 25) (National Association of Friendship Centres, n.d.).

In keeping with an Aboriginal population that is younger overall, research shows that 41 percent of off-reserve First Nations people (without specifying whether these are urban areas) are between the ages of 25 and 54 (Statistics Canada 2008, 44) and 45 percent of Inuit people living in urban areas are 25 to 64 years of age (Statistics Canada 2008, 23). 
Looking at five major urban centres, between 38 percent and 50 percent of the Aboriginal population, but only 30 percent to 34 percent of the non-Aboriginal population, in each instance is under 25 years of age (Urban Aboriginal Task Force 2007, 56).

Clearly, taken together, there are still large gaps in knowledge about the gender and age makeup of the urban Aboriginal population.

\section{Income}

Usually, when Aboriginal incomes are examined, the focus is primarily on income disparities between Aboriginal and non-Aboriginal people and the issues that arise with poverty among Aboriginal people. Aboriginal people, as a whole, have lower household incomes (Bopp, Bopp, and Lane Jr. 2003). The median individual income for Aboriginal people in 2006 was $\$ 18,962$, which is 30 percent lower than the $\$ 27,097$ median individual income for non-Aboriginal people. This income disparity is narrowing very slowly over time but, at its current rate, it will take more than 60 years for the gap to close (Wilson and Macdonald 2010,3). Lower incomes suggest, in addition to other issues, higher stresses, greater vulnerability to fluctuations in the housing market, and poorer health outcomes for the Aboriginal population (Statistics Canada 2008; Ipsos-Reid 2006; Brzozowski, TaylorButts, and Johnson 2006).

However, research on urban Aboriginal people has recently uncovered some promising trends. It appears that there is an emerging, urban, Aboriginal middle-income group (defined in the cited research as earning an annual household income of between $\$ 40,000$ and \$60,000). In the six cities in Ontario included in the Urban Aboriginal Task Force research report, "25.4 percent of the local Aboriginal population was earning over $\$ 40,000$ per year and 12.3 percent was earning over $\$ 60,000$ per year" (Urban Aboriginal Task Force 2007, 171). Among the cities where Aboriginal respondents live, the highest proportion of respondents earning over \$40,000 was in Barrie/Midland/Orillia (38 percent), with Ottawa (32\%) and Sudbury (29\%) having slightly lower proportions (172).

\section{The Issue}

While the preceding research describes some characteristics of the Aboriginal urban population, it also raises many questions; the changing income profile, in particular, is not well understood. Much of the national research on Aboriginal people in urban areas cannot be disaggregated into First Nations, Métis, and Inuit people because the data is not collected at this granular a level. This limits the responses of policy makers and service providers as they do not have the information to tailor services for specific Aboriginal populations, which may have differing needs. As well, in spite of the understanding that much of the First Nations population lives off-reserve in urban areas, not much research has been undertaken to analyze the demography and makeup of this population, either on its own or relative to other Aboriginal people in urban areas. Some findings suggest that First Nations in urban areas are a markedly heterogeneous group, making it difficult for them to find ethnic social cohesion, culture and language retention, and a community feeling in their urban setting (Clatworthy 2000). Furthermore, in a recent study of 725 First Nations individuals in Hamilton, 90 percent of the survey sample had moved once in 
the preceding five years and over 50 percent of the population had moved three times in the same time frame. In this group, only 3 percent spoke an Aboriginal language at home, and 78.2 percent had personal incomes below \$20,000 in 2008 (Smylie et al. 2011, 3233). Clearly, First Nations people in Hamilton are not thriving. Given Clatworthy's (2000) findings, it may be that First Nations people in urban centres are not thriving overall. And how are other Aboriginal people doing by comparison? We know that there is an urban Aboriginal middle-income group, for example, but who comprises this group?

In addition to the fact that there is only limited information available on the demography of urban Aboriginal people, the extent to which an urban Aboriginal middle-income group exists in cities across Canada, or what characteristics have made this group successful in urban environments, is not well known. There is little information on the differences between urban First Nations people, as compared to other urban Aboriginal people. While much of the existing research on Aboriginal people focuses on the challenges they face, this article will have a more positive focus by working to uncover details of this promising, middle-income group of urban Aboriginal people and by examining how the middleincome group differs between First Nations and other Aboriginal people, as well as between Aboriginal and non-Aboriginal people.

\section{Research Questions}

Given these gaps in our understanding, this research was conducted in order to gain a deeper understanding of the urban Aboriginal middle-income group in Canada, and focused on answering the following questions:

- On a national level, how large is the urban Aboriginal middle-income group, both in absolute terms and relative to lower-income and higher-income urban Aboriginal people?

- In what regions and cities does the urban Aboriginal middle-income group tend to be concentrated or absent? What is the comparative concentration of the lower-income and higher-income urban Aboriginal groups in these cities?

- What are the age, gender, mobility, education, employment, and language characteristics of the urban Aboriginal middle-income group, and how do these characteristics compare to those of the lower and higher-income urban Aboriginal groups?

- Within each of these groups, are there differences for First Nations people relative to other Aboriginal people?

- Within each of these groups, are there differences for Aboriginal People relative to non-Aboriginal people?

\section{Method}

This analysis focused on data from 2006 Aboriginal Peoples Survey and the 2006 Census. For this analysis, "urban" was defined as an area with a total population of at least 1,000 people and a population density of no fewer than 400 people per square kilometre. 
Aboriginal people were defined as those who responded positively to the identification questions in the APS, and all persons in the Aboriginal identity population were included in this sample. It is important to note that the APS sample excludes First Nations living onreserve. First Nations people were those who responded positively to the Census questions "Are you a Treaty Indian or a Registered Indian as defined by the Indian Act of Canada?" and "Are you a member of an Indian Band or First Nation?" All other Aboriginal people were included in one category that included non-status Indians, Métis, and Inuit people. Within the Census data, the comparison sample of interest was that of non-Aboriginal people in urban areas.

Income breaks in the APS were decided by applying the rule used in previous Statistics Canada studies with all Canadian households in the 2006 Census. Middle-income was defined by taking 75 percent to 150 percent of the income distribution, which was $\$ 40,226$ to $\$ 80,451$ in the 2006 Census. Lower and higher incomes were defined as the income below the lower boundary and above the higher boundary (Heisz 2007). These same income categories were used with Census data for comparability purposes.

Statistics Canada conducted data runs from the APS for the Aboriginal population, stratified by urban versus rural status, by income, and by First Nations (registered Indians) versus other Aboriginal status. Weighting was done using a series of seven steps, including bootstrapping (see Statistics Canada 2008, 19-22, for a detailed description), and analyses were conducted on this data. An initial comparison was conducted of income for urban versus rural Aboriginal people in order to provide context. All remaining demographic analyses focused only on urban Aboriginal people. Census data for non-Aboriginal people were stratified in the same manner as the APS data and used for comparison purposes where available.

\section{Limitations}

The data from the Aboriginal Peoples Survey (APS) appeared to inflate the numbers of Aboriginal people in the middle- and higher-income groups, based on the proportions in the groups in the Aboriginal and non-Aboriginal population and research demonstrating the much lower income of Aboriginal people, as compared to non-Aboriginal people (Smylie et al. 2011). This inflation might have taken place because of the APS methodology, as the APS survey uses a sampling frame with a construction based on all individuals who responded positively to the Aboriginal questions in the Census long form sample. The Census is known to have significant under-participation by First Nations community members, and "is known to under-represent persons who are homeless, transient, or who have low literacy skills, all issues which have higher prevalence in First Nations populations, and all issues that are associated with lower income levels" (Smylie et al. 2011, 35). Further, while the Census does include some on-reserve population, the APS does not include people living in on-reserve communities in the provinces and First Nations in the territories (Aboriginal Peoples Survey n.d.). As a result, APS respondents would likely be those who are in the higher income levels.

Even taken together, these factors still do not explain why the income levels of First Nations in this data were much higher than expected. Across Canada, in 2005, First Nations 
off-reserve had a median income of $\$ 22,500$, which dropped while on-reserve to $\$ 14,000$ (Statistics Canada 2010). This means that the most affluent First Nations are those included in both the Census and the Aboriginal Peoples Survey. It could well be that these higher income levels are due to the influence of ethnic mobility, where some of those who are selfidentifying as Aboriginal people are also in the higher income categories.

Further, these analyses were provided by Statistics Canada in table format examining only one variable at a time. In this way, inter-relationships between variables have not been identified or analyzed, leaving some gaps in our understanding of these variables.

Finally, a single definition of income classes was used with no consideration for household size, cost of living in various regions, etc.

\section{Analysis}

Comparisons between subgroups were analyzed using two-tailed z-tests of differences between two population proportions. These tests determine whether the difference between the two population proportions being compared is significantly different from zero. Due to the number of tests performed, a more stringent criterion of $\alpha=.01$ was used. This is an extremely reasonable approach, according to both Harlow (2005) and Pagano (2010), when there is a need to protect the Type I error rate without increasing the probably of a Type $\mathrm{II}^{4}$ error too dramatically. Significant differences are noted in the tables. In order to focus on the most important trends, given the power in the sample, only significant differences that are equal to or greater than 5 percent are discussed in the text.

\section{Results}

The results begin with an overview of Aboriginal people, non-Aboriginal people, and household incomes in all areas of Canada (first by urban, rural, and Inuit Nunangat location and, second, by jurisdiction), excluding First Nations on reserve, in order to set the context for urban Aboriginal people. The remainder of the results section examines urban areas of Canada only, which is the focus of this article. The income profile of First Nations (offreserve) and other Aboriginal people in urban areas is examined in comparison to nonAboriginal people in urban areas according to a series of factors. It is examined, one factor at a time, for Census Metropolitan Area (CMA) and Census area (CA), age group, gender, mobility, education, employment status, and language. Language focuses first on official languages and second on Aboriginal languages.

Description of Aboriginal People, Non-Aboriginal People, and Household Incomes Across the Country

In order to provide the overall context for the Aboriginal middle-income group, it is important to understand where this group is situated compared to other income groups, how First Nations and other Aboriginal people compared on these incomes, and how Aboriginal income groups, including the middle-income group, compare to non-Aboriginal

4 Type I error is the error made when the tested hypothesis is rejected even though it is true. Type II errors are made when the null hypothesis is not rejected even though it is false (Hays 1994, 282). 
people. Table 1 presents the proportions of all Aboriginal people (excluding First Nations on-reserve) and their household incomes in urban, rural, and Inuit Nunangat regions, as well as non-Aboriginal people in urban and rural regions.

As seen in Table 1, there were similar proportions of Aboriginal (total Aboriginal, First Nations, and other Aboriginal people alike) and non-Aboriginal people in the middleincome household category (about a third). The differences between these groups were found in the higher- and lower-income household categories. Higher proportions of Aboriginal people compared to non-Aboriginal people were in lower-income households, a difference that was driven in part by the proportion of First Nations in this category. In fact, a plurality of First Nations was in the low household income category (and in urban areas) while, on the other end of the spectrum, a plurality of non-Aboriginal people was in the high household income category in urban areas.

TABLE 1: Household Incomes for Aboriginal People (First Nations, Other Aboriginal and Total Aboriginal People) and non-Aboriginal People

\begin{tabular}{|c|c|c|c|c|}
\hline \multirow{2}{*}{ Population } & \multirow{2}{*}{ Location } & Low Income & Middle-income & High Income \\
\hline & & $\begin{array}{l}\text { Less than } \$ 20,000 \\
\text { to } \$ 40,225\end{array}$ & $\begin{array}{c}\$ 40,226 \text { to } \\
\$ 80,451\end{array}$ & above $\$ 80,451$ \\
\hline \multirow{4}{*}{ First Nations } & Canada & $41 \%$ & $33 \%$ & $26 \%$ \\
\hline & Urban & $43 \%{ }^{*} t$ & $32 \%{ }^{*} t$ & $25 \%{ }^{*} t$ \\
\hline & Rural & $36 \%{ }^{*} t$ & $36 \%{ }^{*}+$ & $27 \%{ }^{*}+$ \\
\hline & Inuit Nunangat & $28 \%{ }^{*}$ & $26 \%{ }^{*} \dagger$ & $46 \%{ }^{*} t$ \\
\hline \multirow{4}{*}{ Other Aboriginal } & Canada & $31 \%$ & $35 \%$ & $35 \%$ \\
\hline & Urban & $31 \%^{\dagger}$ & $34 \%{ }^{*} t$ & $35 \%{ }^{*} t$ \\
\hline & Rural & $30 \%{ }^{*} t$ & $37 \%{ }^{*} t$ & $33 \%{ }^{*} t$ \\
\hline & Inuit Nunangat & $30 \%$ & $35 \%^{t}$ & $35 \%{ }^{*} t$ \\
\hline \multirow{4}{*}{ Total Aboriginal } & Canada & $34 \%$ & $34 \%{ }^{*}$ & $31 \%$ \\
\hline & Urban & $35 \%{ }^{*}$ & $34 \%$ & $31 \%$ \\
\hline & Rural & $32 \%{ }^{*}$ & $37 \%^{*}$ & $31 \%{ }^{*}$ \\
\hline & Inuit Nunangat & $30 \%{ }^{*}$ & $34 \%$ & $36 \%{ }^{*}$ \\
\hline \multirow{3}{*}{ Non-Aboriginal } & Canada & $26 \%^{n}$ & $34 \%$ & $39 \%^{n}$ \\
\hline & Urban & $26 \%{ }^{n}$ & $34 \%$ & $40 \%^{n}$ \\
\hline & Rural & $27 \%^{n}$ & $38 \%^{n}$ & $35 \%^{n}$ \\
\hline
\end{tabular}

* Statistically significant difference between specific area in Canada (rural, urban, Inuit Nunangat) and total population of Canada (excluding First Nations on-reserve), $p<0.01$, Z-test of two population proportions

$\dagger$ Statistically significant difference between First Nations off-reserve and other Aboriginal people within the same area of Canada, $\mathrm{p}<0.01$, Z-test of two population proportions

$\mathrm{n}$ Statistically significant difference between total Aboriginal and non-Aboriginal people within the same area of Canada, $\mathrm{p}<0.01$, Z-test of two population proportions 
The remainder of the tables are focused on urban areas only. Note that the data for Aboriginal groups excludes First Nations on-reserve and that for non-Aboriginal people, while data were collected for on-reserve populations, these data were not included in the urban sample of interest.

\section{Urban Aboriginal and non-Aboriginal Household Incomes by Jurisdiction}

In this section, we examined household income by jurisdiction for all Aboriginal people, and then compared First Nations off-reserve in each jurisdiction to other Aboriginal people in each jurisdiction to see where the differences among Aboriginal people might lie. Finally, we compared Aboriginal and non-Aboriginal household incomes by jurisdiction in urban areas across the country.

Aboriginal household incomes were, roughly, distributed equally across the low, middle, and high-income categories in urban areas. Greater proportions of higherincome Aboriginal households were in the Northwest Territories and Alberta, the highest proportions of middle-income households were in Quebec, followed by Nova Scotia, and the greatest proportion of lower-income households was in the Yukon, followed by Saskatchewan.

About a third of both First Nations and other Aboriginal households were in the middle household-income category. While results from Table 1 showed that the difference between the two groups was in the proportions in the higher and lower household-income categories, Table 2 outlined the larger proportions of other Aboriginal people in the higher householdincome category in each jurisdiction examined other than in New Brunswick, where there were similar proportions in the highest household-income categories. Conversely, there were higher proportions of First Nations households in comparison to other Aboriginal households in the lower-income category in every jurisdiction examined.

Comparing Aboriginal and non-Aboriginal household income by jurisdiction showed that the proportion of middle-income households were generally similar across jurisdictions. In each jurisdiction, other than Newfoundland and Labrador (where proportions were similar), there were lower proportions of Aboriginal people than non-Aboriginal people in the higher-income category. In all jurisdictions for which numbers were available except Newfoundland and Labrador and Quebec, there were a notably higher proportion of Aboriginal than non-Aboriginal people in the lower-income category than among nonAboriginal people.

Results show that First Nations households generally have lower income levels than the income levels of other Aboriginal households, across jurisdictions, and that Aboriginal middle-income household levels are similar to non-Aboriginal middle-income household levels. The differences between these two groups are in the income extremes: there were generally fewer Aboriginal households in higher-income categories and generally more Aboriginal households in the lower-income category. 
TABLE 2: Household Incomes by Jurisdiction for Aboriginal People (First Nations, Other Aboriginal and Total Aboriginal People) and non-Aboriginal People (percent)

\begin{tabular}{|c|c|c|c|c|}
\hline \multirow{2}{*}{ Population } & \multirow{2}{*}{ Jurisdiction (urban areas) } & $\begin{array}{c}\text { Low } \\
\text { Income }\end{array}$ & $\begin{array}{l}\text { Middle- } \\
\text { income }\end{array}$ & $\begin{array}{c}\text { High } \\
\text { Income }\end{array}$ \\
\hline & & $\begin{array}{c}\text { Less than } \\
\$ 40,226\end{array}$ & $\begin{array}{c}\$ 40,226 \text { to } \\
\$ 80,451\end{array}$ & $\begin{array}{c}\text { above } \\
\$ 80,451\end{array}$ \\
\hline \multirow{14}{*}{$\begin{array}{l}\text { First Nations } \\
\text { Off-Reserve }\end{array}$} & Canada & $42.6 \%{ }^{\dagger}$ & $32.3 \%{ }^{\dagger}$ & $25.1 \%^{\dagger}$ \\
\hline & $\begin{array}{l}\text { Newfoundland and } \\
\text { Labrador }\end{array}$ & $42.3 \%^{\dagger}$ & $27.7 \%{ }^{*}+$ & $30.1 \%{ }^{*}+$ \\
\hline & Prince Edward Island & N/A & N/A & $\mathrm{N} / \mathrm{A}$ \\
\hline & Nova Scotia & $43.6 \%^{\dagger}$ & $33.1 \%{ }^{\dagger}$ & $23.3 \%{ }^{*}+$ \\
\hline & New Brunswick & $44.8 \%$ & $31.3 \%$ & $24.0 \%$ \\
\hline & Quebec & $43.6 \%^{\dagger}$ & $36.7 \%{ }^{*}+$ & $19.7 \%^{*}{ }^{*}$ \\
\hline & Ontario & $39.0 \%{ }^{*} t$ & $31.4 \%{ }^{*}$ & $29.6 \%{ }^{*}+$ \\
\hline & Manitoba & $50.5 \%{ }^{*} t$ & $31.2 \%{ }^{*}+$ & $18.3 \%{ }^{*}+$ \\
\hline & Saskatchewan & $55.4 \%{ }^{*} t$ & $29.4 \%{ }^{*} \dagger$ & $15.2 \%{ }^{*} \dagger$ \\
\hline & Alberta & $34.5 \%{ }^{*}+$ & $31.7 \%{ }^{*}+$ & $33.8 \%{ }^{*}+$ \\
\hline & British Columbia & $43.8 \%{ }^{*}+$ & $34.6 \%{ }^{*}$ & $21.6 \%{ }^{*}+$ \\
\hline & Yukon & $47.6 \%{ }^{*}$ & $26.2 \%{ }^{*}+$ & $26.2 \%^{\dagger}$ \\
\hline & Northwest Territories & $30.8 \%{ }^{*} t$ & $21.4 \%{ }^{*}$ & $47.8 \%{ }^{*}+$ \\
\hline & Nunavut & $\mathrm{N} / \mathrm{A}$ & $\mathrm{N} / \mathrm{A}$ & $\mathrm{N} / \mathrm{A}$ \\
\hline \multirow{14}{*}{ Other Aboriginal } & Canada & $30.6 \%^{\dagger}$ & $34.3 \%^{\dagger}$ & $35.1 \%^{\dagger}$ \\
\hline & $\begin{array}{l}\text { Newfoundland and } \\
\text { Labrador }\end{array}$ & $32.2 \%{ }^{*} t$ & $32.1 \%{ }^{*}+$ & $35.7 \%^{\dagger}$ \\
\hline & Prince Edward Island & N/A & $\mathrm{N} / \mathrm{A}$ & $\mathrm{N} / \mathrm{A}$ \\
\hline & Nova Scotia & $38.4 \%{ }^{*}+$ & $36.2 \%{ }^{*}+$ & $25.4 \%^{*}+$ \\
\hline & New Brunswick & $43.6 \%{ }^{*}$ & $32.7 \%{ }^{*}$ & $23.7 \%{ }^{*}$ \\
\hline & Quebec & $33.4 \%{ }^{*}+$ & $38.0 \%{ }^{*}+$ & $28.6 \%{ }^{*}+$ \\
\hline & Ontario & $30.3 \%^{t}$ & $31.7 \%{ }^{*}$ & $38.0 \%{ }^{*}+$ \\
\hline & Manitoba & $33.2 \%{ }^{*}+$ & $33.6 \%{ }^{*}+$ & $33.2 \%{ }^{*}+$ \\
\hline & Saskatchewan & $36.9 \%{ }^{*}+$ & $34.6 \%^{\dagger}$ & $28.5 \%{ }^{*}+$ \\
\hline & Alberta & $21.8 \%{ }^{*}+$ & $34.3 \%^{t}$ & $43.9 \%{ }^{*}+$ \\
\hline & British Columbia & $30.6 \%^{t}$ & $35.1 \%{ }^{*}$ & $34.3 \%{ }^{*}+$ \\
\hline & Yukon & $45.2 \%{ }^{*}$ & $0.0 \%{ }^{*}+$ & $54.8 \%{ }^{*}+$ \\
\hline & Northwest Territories & $0.0 \%{ }^{*} t$ & $19.7 \%^{*}$ & $80.3 \%{ }^{*}+$ \\
\hline & Nunavut & N/A & $\mathrm{N} / \mathrm{A}$ & $\mathrm{N} / \mathrm{A}$ \\
\hline \multirow{7}{*}{ Total Aboriginal } & Canada & $35.1 \%$ & $33.5 \%$ & $31.3 \%$ \\
\hline & $\begin{array}{l}\text { Newfoundland and } \\
\text { Labrador }\end{array}$ & $35.8 \%$ & $30.5 \%{ }^{*}$ & $33.7 \%{ }^{*}$ \\
\hline & Prince Edward Island & $\mathrm{N} / \mathrm{A}$ & N/A & N/A \\
\hline & Nova Scotia & $39.8 \%{ }^{*}$ & $35.3 \%{ }^{*}$ & $24.8 \%{ }^{*}$ \\
\hline & New Brunswick & $44.0 \%{ }^{*}$ & $32.3 \%{ }^{*}$ & $23.7 \%{ }^{*}$ \\
\hline & Quebec & $35.6 \%{ }^{*}$ & $37.7 \%{ }^{*}$ & $26.7 \%^{*}$ \\
\hline & Ontario & $33.5 \%{ }^{*}$ & $31.6 \%{ }^{*}$ & $34.9 \%{ }^{*}$ \\
\hline
\end{tabular}




\begin{tabular}{|c|c|c|c|c|}
\hline \multirow{9}{*}{ Population } & \multirow{2}{*}{ Jurisdiction (urban areas) } & $\begin{array}{c}\text { Low } \\
\text { Income }\end{array}$ & $\begin{array}{l}\text { Middle- } \\
\text { income }\end{array}$ & $\begin{array}{c}\text { High } \\
\text { Income }\end{array}$ \\
\hline & & $\begin{array}{c}\text { Less than } \\
\$ 40,226\end{array}$ & $\begin{array}{c}\$ 40,226 \text { to } \\
\$ 80,451\end{array}$ & $\begin{array}{c}\text { above } \\
\$ 80,451\end{array}$ \\
\hline & Manitoba & $40.7 \%^{*}$ & $32.6 \%{ }^{*}$ & $26.7 \%{ }^{*}$ \\
\hline & Saskatchewan & $46.4 \%^{*}$ & $31.9 \%{ }^{*}$ & $21.6 \%{ }^{*}$ \\
\hline & Alberta & $26.6 \%{ }^{*}$ & $33.3 \%$ & $40.1 \%{ }^{*}$ \\
\hline & British Columbia & $36.6 \%{ }^{*}$ & $34.9 \%{ }^{*}$ & $28.5 \%{ }^{*}$ \\
\hline & Yukon & $47.2 \%{ }^{*}$ & $22.1 \%{ }^{*}$ & $30.6 \%$ \\
\hline & Northwest Territories & $19.5 \%{ }^{*}$ & $20.8 \%{ }^{*}$ & $59.7 \%{ }^{*}$ \\
\hline & Nunavut & $\mathrm{N} / \mathrm{A}$ & $\mathrm{N} / \mathrm{A}$ & $\mathrm{N} / \mathrm{A}$ \\
\hline \multirow{14}{*}{ Non-Aboriginal } & Canada & $26.3 \%^{n}$ & $33.5 \%$ & $40.2 \%^{n}$ \\
\hline & $\begin{array}{l}\text { Newfoundland and } \\
\text { Labrador }\end{array}$ & $32.6 \%{ }^{n}$ & $35.2 \%{ }^{n}$ & $32.2 \%^{n}$ \\
\hline & Prince Edward Island & $34.0 \%$ & $38.0 \%$ & $28.0 \%$ \\
\hline & Nova Scotia & $33.7 \%^{n}$ & $35.4 \%$ & $30.9 \%^{n}$ \\
\hline & New Brunswick & $32.4 \%{ }^{n}$ & $36.5 \%^{n}$ & $31.1 \%^{n}$ \\
\hline & Quebec & $31.7 \%^{n}$ & $36.2 \%^{n}$ & $32.1 \%^{n}$ \\
\hline & Ontario & $23.6 \%^{n}$ & $31.7 \%$ & $44.7 \%^{n}$ \\
\hline & Manitoba & $27.3 \%^{n}$ & $36.9 \%^{n}$ & $35.8 \%^{n}$ \\
\hline & Saskatchewan & $27.1 \%^{n}$ & $35.2 \%^{n}$ & $37.7 \%^{n}$ \\
\hline & Alberta & $19.8 \%{ }^{n}$ & $32.0 \%{ }^{n}$ & $48.1 \%^{n}$ \\
\hline & British Columbia & $27.3 \%^{n}$ & $33.9 \%^{n}$ & $38.8 \%^{n}$ \\
\hline & Yukon & $16.8 \%{ }^{n}$ & $29.3 \%^{n}$ & $53.9 \%^{n}$ \\
\hline & Northwest Territories & $8.3 \%^{n}$ & $17.9 \%^{n}$ & $73.8 \%^{n}$ \\
\hline & Nunavut & $8.2 \%$ & $16.7 \%$ & $75.2 \%$ \\
\hline
\end{tabular}

* Statistically significant difference between specific jurisdiction and total population of urban areas of Canada (excluding First Nations on-reserve), $\mathrm{p}<0.01$, Z-test of two population proportions

$\dagger$ Statistically significant difference between First Nations off-reserve and other Aboriginal people within the same jurisdiction, $\mathrm{p}<0.01$, Z-test of two population proportions

$\mathrm{n}$ Statistically significant difference between total Aboriginal and non-Aboriginal people within the same jurisdiction, $\mathrm{p}<0.01$, Z-test of two population proportions 
Urban Aboriginal and non-Aboriginal Household Income by Census Metropolitan Area (CMA) and Census area (CA)

We started by examining urban Aboriginal households across Canada by CMAs and CAs. Then we looked at First Nations households in comparison to other urban Aboriginal households across Canada. Finally we examined Aboriginal and non-Aboriginal households across Canada. While data for a large number of census areas and census metropolitan areas were available, only data for CMAs and CAs with a substantial population of Aboriginal persons were included in our final table. As such, income data for nine CA/CMAs was examined (See Table 3).

For all Aboriginal households, the largest proportion in the high-income category was found in Ottawa-Gatineau and Toronto. In the middle-income category, the highest proportion of households was found in Montreal and Calgary, and the highest proportion of lower-income households was in Saskatoon and Regina.

Results showed that there were higher proportions of other Aboriginal households in the higher-income category, compared to First Nations households in every CMA and CA, other than in Ottawa-Gatineau, where the difference was less than 5 percent. A slightly different pattern was found in the middle-income category, where there were no differences between the household incomes of the two groups in Ottawa-Gatineau, Toronto, Winnipeg, and Calgary. However, in the remaining jurisdictions, there were higher proportions of other Aboriginal households in the middle-income category compared to First Nations households.

Looking at all urban Aboriginal households compared to urban non-Aboriginal households by CMA and CA, other than in Montreal and Toronto where proportions are similar, there are higher proportions of non-Aboriginal compared to Aboriginal people in the higher-income category in every jurisdiction. In the middle-income category, there are higher proportions of non-Aboriginal households compared to Aboriginal households in Regina, but there are lower proportions of non-Aboriginal households compared to Aboriginal households in Calgary. There are no differences between Aboriginal and nonAboriginal households in other CMAs and CAs. And, other than Montreal and OttawaGatineau, there are higher proportions of Aboriginal households compared to nonAboriginal households in every CMA and CA in the lower-income category.

To summarize, again, there is a general trend where First Nations households are, proportionately, lower income in comparison to other Aboriginal households, across CMAs and CAs. Non-Aboriginal households are also generally higher income than Aboriginal households. Ottawa-Gatineau and Toronto appears to be holding the wealthiest Aboriginal households. 
TABLE 3: Urban Aboriginal (First Nations, other Aboriginal and total Aboriginal People) and non-Aboriginal Household Income by Census Area/Census Metropolitan Area (percent)

\begin{tabular}{|c|c|c|c|c|}
\hline \multirow[b]{2}{*}{ Population } & \multirow[b]{2}{*}{ CA/CMA } & $\begin{array}{l}\text { Low } \\
\text { Income }\end{array}$ & $\begin{array}{l}\text { Middle- } \\
\text { income }\end{array}$ & $\begin{array}{c}\text { High } \\
\text { Income }\end{array}$ \\
\hline & & $\begin{array}{l}\text { Less than } \\
\$ 40,226\end{array}$ & $\begin{array}{c}\$ 40,226 \text { to } \\
\$ 80,451\end{array}$ & $\begin{array}{c}\text { above } \\
\$ 80,451\end{array}$ \\
\hline \multirow{10}{*}{$\begin{array}{l}\text { First Nations } \\
\text { Off-Reserve }\end{array}$} & Canada & $42.6 \%^{\dagger}$ & $32.3 \%^{\dagger}$ & $25.1 \%^{\dagger}$ \\
\hline & Montréal & $39.2 \%^{* t}$ & $38.4 \%^{*+}$ & $22.5 \%{ }^{*} t$ \\
\hline & Ottawa-Gatineau & $28.4 \%^{*+}$ & $34.5 \%{ }^{*}$ & $37.0 \%{ }^{*} t$ \\
\hline & Toronto & $35.9 \%^{*+}$ & $28.7 \%^{*}$ & $35.4 \%^{*}+$ \\
\hline & Winnipeg & $50.9 \%{ }^{*}+$ & $32.9 \%$ & $16.1 \%{ }^{*} t$ \\
\hline & Regina & $58.1 \%^{*}{ }^{*}$ & $25.9 \%{ }^{*}+$ & $16.0 \%{ }^{*} t$ \\
\hline & Saskatoon & $57.8 \%^{*+}$ & $29.7 \%^{*}{ }^{*}$ & $12.5 \%{ }^{*} t$ \\
\hline & Calgary & $34.2 \%{ }^{*+}$ & $36.2 \%{ }^{*}$ & $29.6 \%{ }^{*} t$ \\
\hline & Edmonton & $39.1 \%^{*+}$ & $31.2 \%^{*}+$ & $29.7 \%^{*} t$ \\
\hline & Vancouver & $43.4 \%^{\dagger}$ & $31.9 \%^{\dagger}$ & $24.7 \%^{t}$ \\
\hline \multirow{10}{*}{ Other Aboriginal } & Canada & $30.7 \%^{\dagger}$ & $34.3 \%^{\dagger}$ & $35.0 \%^{\dagger}$ \\
\hline & Montréal & $27.6 \%{ }^{*+}$ & $40.0 \%{ }^{*+}$ & $32.3 \%^{*} t$ \\
\hline & Ottawa-Gatineau & $24.7 \%^{*+}$ & $33.5 \%{ }^{*}$ & $41.8 \%^{*} t$ \\
\hline & Toronto & $25.2 \%^{*+}$ & $28.0 \%^{*}$ & $46.9 \%^{*}+$ \\
\hline & Winnipeg & $32.5 \%{ }^{*}+$ & $33.7 \%{ }^{*}$ & $33.8 \%{ }^{* t}$ \\
\hline & Regina & $33.2 \%^{*+}$ & $31.9 \%{ }^{*}+$ & $34.9 \%{ }^{*} t$ \\
\hline & Saskatoon & $35.2{ }^{*}{ }^{*}$ & $39.1 \%^{*}{ }^{*}$ & $25.7 \%^{*}+$ \\
\hline & Calgary & $19.5 \%{ }^{*}{ }^{+}$ & $37.4 \%^{*}$ & $43.1 \%{ }^{*} t$ \\
\hline & Edmonton & $24.3 \%{ }^{*+}$ & $34.2 \%^{\dagger}$ & $41.6 \%{ }^{*} t$ \\
\hline & Vancouver & $28.0 \%^{*}{ }^{*}$ & $34.0 \%{ }^{*}+$ & $38.0 \%^{t}$ \\
\hline \multirow{10}{*}{ Total Aboriginal } & Canada & $35.1 \%$ & $33.6 \%$ & $31.3 \%$ \\
\hline & Montréal & $29.3 \%{ }^{*}$ & $39.8 \%{ }^{*}$ & $30.9 \%^{*}$ \\
\hline & Ottawa-Gatineau & $25.7 \%^{*}$ & $33.8 \%$ & $40.4 \%{ }^{*}$ \\
\hline & Toronto & $28.5 \%^{*}$ & $28.2 \%{ }^{*}$ & $43.3 \%{ }^{*}$ \\
\hline & Winnipeg & $40.1 \%{ }^{*}$ & $33.4 \%{ }^{*}$ & $26.5 \%{ }^{*}$ \\
\hline & Regina & $46.5 \%{ }^{*}$ & $28.7 \%^{*}$ & $24.8 \%{ }^{*}$ \\
\hline & Saskatoon & $47.4 \%^{*}$ & $34.0 \%$ & $18.6 \%{ }^{*}$ \\
\hline & Calgary & $24.3 \%{ }^{*}$ & $37.0 \%{ }^{*}$ & $38.7 \%{ }^{*}$ \\
\hline & Edmonton & $30.1 \%{ }^{*}$ & $33.0 \%{ }^{*}$ & $36.9 \%{ }^{*}$ \\
\hline & Vancouver & $34.0 \%{ }^{*}$ & $33.2 \%{ }^{*}$ & $32.8 \%{ }^{*}$ \\
\hline
\end{tabular}




\begin{tabular}{|c|c|c|c|c|}
\hline \multirow[b]{2}{*}{ Population } & \multirow[b]{2}{*}{ CA/CMA } & $\begin{array}{c}\text { Low } \\
\text { Income }\end{array}$ & $\begin{array}{l}\text { Middle- } \\
\text { income }\end{array}$ & $\begin{array}{c}\text { High } \\
\text { Income }\end{array}$ \\
\hline & & $\begin{array}{c}\text { Less than } \\
\$ 40,226\end{array}$ & $\begin{array}{c}\$ 40,226 \text { to } \\
\$ 80,451\end{array}$ & $\begin{array}{c}\text { above } \\
\$ 80,451\end{array}$ \\
\hline \multirow{10}{*}{ Non-Aboriginal } & Canada & $26.3 \%^{n}$ & $33.5 \%^{n}$ & $40.2 \%^{n}$ \\
\hline & Montréal & $31.1 \%^{n}$ & $35.2 \%^{n}$ & $33.8 \%^{n}$ \\
\hline & Ottawa-Gatineau & $21.5 \%^{n}$ & $29.8 \%^{n}$ & $48.7 \%^{n}$ \\
\hline & Toronto & $22.9 \%^{n}$ & $30.0 \%^{n}$ & $47.1 \%^{n}$ \\
\hline & Winnipeg & $26.3 \%^{n}$ & $36.5 \%^{n}$ & $37.1 \%^{n}$ \\
\hline & Regina & $22.8 \%^{n}$ & $34.4 \%^{n}$ & $42.8 \%^{n}$ \\
\hline & Saskatoon & $26.8 \%^{n}$ & $35.1 \%^{n}$ & $38.1 \%^{n}$ \\
\hline & Calgary & $18.4 \%^{n}$ & $31.2 \%^{n}$ & $50.4 \%^{n}$ \\
\hline & Edmonton & $20.9 \%^{n}$ & $31.9 \%^{n}$ & $47.2 \%^{n}$ \\
\hline & Vancouver & $26.8 \%^{n}$ & $32.2 \%^{n}$ & $40.9 \%^{n}$ \\
\hline
\end{tabular}

* Statistically significant difference between specific CA/CMA and total population of urban areas of Canada (excluding First Nations on-reserve), $\mathrm{p}<0.01$, Z-test of two population proportions

$\uparrow$ Statistically significant difference between First Nations off-reserve and other Aboriginal people within the same CA/CMA, $\mathrm{p}<0.01$, Z-test of two population proportions

$\mathrm{n}$ Statistically significant difference between total Aboriginal and non-Aboriginal people within the same CA/CMA, $\mathrm{p}<0.01$, Z-test of two population proportions

\section{Urban Aboriginal and non-Aboriginal Household Income by Age}

In this section, we compared urban Aboriginal people by age and by income across urban regions in Canada, and followed it with an examination of urban First Nations households by age and by income in comparison to other urban Aboriginal households in Canada. Finally, we compared Aboriginal and non-Aboriginal households by age and income.

The oldest Aboriginal people were the most likely to be in the lower-income category, and the highest proportions in the middle-income category were individuals 25 to 44 years of age (see Table 4). The largest proportions in the high-income category were made up of Aboriginal people between 45 and 54 years of age.

To understand where the differences were occurring within the Aboriginal population, we compared First Nations and other Aboriginal household income by age. With a few exceptions at the extremes, there were generally lower proportions of First Nations in comparison to other Aboriginal households in the higher- and middle-income categories. In contrast there were greater proportions of First Nations people compared to other Aboriginal people in the lower-income category.

A very similar trend was seen in comparisons between Aboriginal and non-Aboriginal urban people across Canada, where there were proportionately fewer Aboriginal than nonAboriginal people in either the high or middle-income categories, and proportionately higher Aboriginal compared to non-Aboriginal people in the low household-income category. 
Similar to the pattern seen with other factors that were tested in this article, the trend was that First Nations tended to have lower household incomes as compared to other Aboriginal people, and this was the case across many age groups. As well, Aboriginal household incomes tended to be lower than non-Aboriginal household incomes.

\section{Urban Aboriginal and non-Aboriginal Household Income by Gender}

This section focuses on household income differences between Aboriginal men and women in urban areas, between First Nations men and women and other Aboriginal men and women, and between urban Aboriginal men and women and non-Aboriginal men and women.

Looking at all Aboriginal people, there were higher proportions of men and lower proportions of women in the highest and middle-income categories (Table 5). Aboriginal women, however, were over-represented in the lower-income category, in comparison to Aboriginal men.

There were lower proportions of First Nations men and women compared to other Aboriginal men and women in the high- and middle-income categories, and higher proportions of First Nations men and women in the lower-income category.

In the high-income category, both Aboriginal men and women were proportionately less well represented compared to non-Aboriginal men and women. Conversely, in the lower-income category, Aboriginal men and women were proportionately more represented compared to non-Aboriginal men and women. There were no differences in the proportion of Aboriginal men and Aboriginal women in the middle-income category in comparison to their non-Aboriginal counterparts.

Taken together, these results suggest that while Aboriginal women have lower incomes than Aboriginal men, this difference is not as great as the difference found simply by having or not having First Nations status. As well, when compared to the Canadian population at large, Aboriginal men and women are more likely to have lower incomes and less likely to have higher incomes, though there is no difference in the proportion in the middle-income groups.

\section{Aboriginal Income by Mobility}

We investigated data on the number of moves in the previous five years by the income breakdowns for urban Aboriginal people. Urban Aboriginal households with high incomes were different than low- and middle-income urban Aboriginal people across Canada in that they were much less likely to have moved four or more times in the last five years (see Table 6). There were no differences of note in the proportion in the middle-income household category based on frequency of moving. Urban Aboriginal people in lowerincome households were more likely than middle- and lower-income Aboriginal people across Canada to have moved five or more times. Overall, mobility increased as income decreased at the income extremes. 
TABLE 4: Urban Aboriginal (First Nations, other Aboriginal and total Aboriginal people) and non-Aboriginal Income by Age (percent)

\begin{tabular}{|c|c|c|c|c|}
\hline \multirow[b]{2}{*}{ Population } & \multirow[b]{2}{*}{ Age Group } & $\begin{array}{c}\text { Low } \\
\text { Income }\end{array}$ & $\begin{array}{l}\text { Middle- } \\
\text { income }\end{array}$ & $\begin{array}{c}\text { High } \\
\text { Income }\end{array}$ \\
\hline & & $\begin{array}{c}\text { Less } \\
\text { than } \\
\$ 40,226\end{array}$ & $\begin{array}{c}\$ 40,226 \\
\text { to } \\
\$ 80,451\end{array}$ & $\begin{array}{c}\text { above } \\
\$ 80,451\end{array}$ \\
\hline \multirow{8}{*}{$\begin{array}{l}\text { First Nations } \\
\text { Off-Reserve }\end{array}$} & Canada (urban areas) & $42.6 \%{ }^{\dagger}$ & $32.3 \%{ }^{\dagger}$ & $25.1 \%{ }^{\dagger}$ \\
\hline & Between the ages of 15 and 19 & $38.7 \%{ }^{*}+$ & $34.4 \%{ }^{*}+$ & $26.9 \%{ }^{*} t$ \\
\hline & Between the ages of 20 and 24 & $50.6 \%{ }^{*} t$ & $27.3 \%{ }^{*}+$ & $22.1 \%{ }^{*} \dagger$ \\
\hline & Between the ages of 25 and 34 & $42.5 \%^{\dagger}$ & $35.3 \%{ }^{*}+$ & $22.2 \%{ }^{*} \dagger$ \\
\hline & Between the ages of 35 and 44 & $38.0 \%{ }^{*} t$ & $34.6 \%{ }^{*}+$ & $27.4 \%{ }^{*} t$ \\
\hline & Between the ages of 45 and 54 & $38.7 \%{ }^{*}+$ & $30.3 \%{ }^{*}+$ & $31.1 \%{ }^{*} \dagger$ \\
\hline & Between the ages of 55 and 64 & $47.2 \%{ }^{*} \dagger$ & $30.7 \%{ }^{*}$ & $22.1 \%{ }^{*} \dagger$ \\
\hline & Age 65 and over & $56.9 \%{ }^{*} \dagger$ & $27.7 \%{ }^{*}+$ & $15.4 \%$ * \\
\hline \multirow{8}{*}{ Other Aboriginal } & Canada (urban areas) & $30.7 \%^{t}$ & $34.3 \%^{\dagger}$ & $35.0 \%{ }^{\dagger}$ \\
\hline & Between the ages of 15 and 19 & $23.0 \%{ }^{*} t$ & $34.0 \%$ & $43.0 \%{ }^{*} t$ \\
\hline & Between the ages of 20 and 24 & $37.0 \%{ }^{*} t$ & $29.0 \%{ }^{*}+$ & $34.0 \%{ }^{*} t$ \\
\hline & Between the ages of 25 and 34 & $33.3 \%{ }^{*}+$ & $38.8 \%{ }^{*}+$ & $27.9 \%{ }^{*} t$ \\
\hline & Between the ages of 35 and 44 & $25.4 \%{ }^{*} \dagger$ & $37.7 \%{ }^{*}+$ & $36.9 \%{ }^{*} t$ \\
\hline & Between the ages of 45 and 54 & $24.5 \%{ }^{*} \dagger$ & $31.2 \%{ }^{*}+$ & $44.4 \%{ }^{*} \dagger$ \\
\hline & Between the ages of 55 and 64 & $37.0 \%{ }^{*}+$ & $30.7 \%{ }^{*}$ & $32.3 \%{ }^{*} t$ \\
\hline & Age 65 and over & $51.5 \%{ }^{*} \dagger$ & $32.7 \%{ }^{*}+$ & $15.8 \%{ }^{*}$ \\
\hline \multirow{8}{*}{ Total Aboriginal } & Canada (urban areas) & $35.1 \%$ & $33.6 \%$ & $31.3 \%$ \\
\hline & Between the ages of 15 and 19 & $29.3 \%{ }^{*}$ & $34.1 \%{ }^{*}$ & $36.6 \%{ }^{*}$ \\
\hline & Between the ages of 20 and 24 & $42.3 \%{ }^{*}$ & $28.3 \%^{*}$ & $29.3 \%{ }^{*}$ \\
\hline & Between the ages of 25 and 34 & $36.7 \%{ }^{*}$ & $37.5 \%{ }^{*}$ & $25.8 \%{ }^{*}$ \\
\hline & Between the ages of 35 and 44 & $30.2 \%{ }^{*}$ & $36.5 \%{ }^{*}$ & $33.3 \%{ }^{*}$ \\
\hline & Between the ages of 45 and 54 & $29.5 \%{ }^{*}$ & $30.9 \%{ }^{*}$ & $39.6 \%{ }^{*}$ \\
\hline & Between the ages of 55 and 64 & $40.7 \%{ }^{*}$ & $30.7 \%{ }^{*}$ & $28.6 \%{ }^{*}$ \\
\hline & Age 65 and over & $53.4 \%{ }^{*}$ & $31.0 \%{ }^{*}$ & $15.7 \%^{*}$ \\
\hline \multirow{8}{*}{ Non-Aboriginal } & Canada (urban areas) & $26.3 \%^{n}$ & $33.5 \%$ & $40.2 \%^{n}$ \\
\hline & Between the ages of 15 and 19 & $20.8 \%{ }^{n}$ & $30.3 \%{ }^{n}$ & $49.0 \%^{n}$ \\
\hline & Between the ages of 20 and 24 & $29.6 \%{ }^{n}$ & $29.0 \%{ }^{n}$ & $41.5 \%^{n}$ \\
\hline & Between the ages of 25 and 34 & $25.2 \%{ }^{n}$ & $37.7 \%$ & $37.2 \%{ }^{n}$ \\
\hline & Between the ages of 35 and 44 & $21.8 \%{ }^{n}$ & $34.1 \%{ }^{n}$ & $44.1 \%^{n}$ \\
\hline & Between the ages of 45 and 54 & $20.1 \%^{n}$ & $30.2 \%{ }^{n}$ & $49.7 \%^{n}$ \\
\hline & Between the ages of 55 and 64 & $26.6 \%{ }^{n}$ & $34.1 \%{ }^{n}$ & $39.2 \%^{n}$ \\
\hline & Age 65 and over & $45.7 \%{ }^{n}$ & $34.5 \%{ }^{n}$ & $19.8 \%{ }^{n}$ \\
\hline
\end{tabular}

* Statistically significant difference between age group and total population in urban areas of Canada (excluding First Nations on-reserve), $\mathrm{p}<0.01$, Z-test of two population proportions

$\dagger$ Statistically significant difference between First Nations off-reserve and other Aboriginal people within the same age group, $\mathrm{p}<0.01, \mathrm{Z}$-test of two population proportions

$\mathrm{n}$ Statistically significant difference between total Aboriginal and non-Aboriginal people within the same age group, $\mathrm{p}<0.01$, Z-test of two population proportions 
TABLE 5: Urban Aboriginal (First Nations, other Aboriginal and total Aboriginal people) and non-Aboriginal Household Income by Gender (percent)

\begin{tabular}{|c|c|c|c|c|}
\hline \multirow[b]{2}{*}{ Population } & \multirow[b]{2}{*}{ Gender } & $\begin{array}{c}\text { Low } \\
\text { Income }\end{array}$ & $\begin{array}{l}\text { Middle- } \\
\text { income }\end{array}$ & $\begin{array}{c}\text { High } \\
\text { Income }\end{array}$ \\
\hline & & $\begin{array}{c}\text { Less } \\
\text { than } \\
\$ 40,226\end{array}$ & $\begin{array}{c}\$ 40,226 \\
\text { to } \\
\$ 80,451\end{array}$ & $\begin{array}{c}\text { above } \\
\$ 80,451\end{array}$ \\
\hline \multirow{3}{*}{$\begin{array}{l}\text { First Nations } \\
\text { Off-Reserve }\end{array}$} & Canada (urban areas) & $42.6 \%{ }^{\dagger}$ & $32.3 \%^{\dagger}$ & $25.1 \%^{\dagger}$ \\
\hline & Male & $38.8 \%{ }^{*} t$ & $34.1 \%{ }^{*} t$ & $27.2 \%{ }^{*}+$ \\
\hline & Female & $45.5 \%{ }^{*} t$ & $31.0 \%{ }^{*} t$ & $23.5 \%{ }^{*}+$ \\
\hline \multirow{3}{*}{ Other Aboriginal } & Canada (urban areas) & $30.7 \%^{\dagger}$ & $34.3 \%^{t}$ & $35.0 \%^{\dagger}$ \\
\hline & Male & $27.3 \%{ }^{*} \dagger$ & $34.9 \%{ }^{*} t$ & $37.8 \%{ }^{*}+$ \\
\hline & Female & $33.5 \%{ }^{*}+$ & $33.8 \%{ }^{*}+$ & $32.7 \%{ }^{*} t$ \\
\hline \multirow{3}{*}{ Total Aboriginal } & Canada (urban areas) & $35.1 \%$ & $33.6 \%$ & $31.3 \%$ \\
\hline & Male & $31.5 \%{ }^{*}$ & $34.6 \%{ }^{*}$ & $34.0 \%{ }^{*}$ \\
\hline & Female & $38.0 \%{ }^{*}$ & $32.7 \%{ }^{*}$ & $29.2 \%{ }^{*}$ \\
\hline \multirow{3}{*}{ Non-Aboriginal } & Canada (urban areas) & $26.3 \%^{n}$ & $33.5 \%$ & $40.2 \%^{n}$ \\
\hline & Male & $23.9 \%^{n}$ & $34.1 \%^{n}$ & $42.0 \%^{n}$ \\
\hline & Female & $28.6 \%^{n}$ & $33.0 \%^{n}$ & $38.5 \%^{n}$ \\
\hline
\end{tabular}

* Statistically significant difference between each gender and the total population in urban areas of Canada, (excluding First Nations on-reserve), $\mathrm{p}<0.01$, Z-test of two population proportions

$\dagger$ Statistically significant difference between First Nations off-reserve and other Aboriginal people within the same gender, $\mathrm{p}<0.01$, Z-test of two population proportions

$\mathrm{n}$ Statistically significant difference between total Aboriginal and non-Aboriginal people within the same gender, $\mathrm{p}<0.01, \mathrm{Z}$-test of two population proportions

TABLE 6: Urban Aboriginal household Income by Mobility (\%)

\begin{tabular}{|c|c|c|c|c|}
\hline \multirow[b]{2}{*}{ Population } & \multirow{2}{*}{$\begin{array}{c}\text { Number of times } \\
\text { moved in the past five } \\
\text { years }\end{array}$} & $\begin{array}{c}\text { Low } \\
\text { Income }\end{array}$ & $\begin{array}{l}\text { Middle- } \\
\text { income }\end{array}$ & $\begin{array}{c}\text { High } \\
\text { Income }\end{array}$ \\
\hline & & $\begin{array}{l}\text { Less than } \\
\$ 20,000 \text { to } \\
\$ 40,225\end{array}$ & $\begin{array}{c}\$ 40,226 \\
\text { to } \\
\$ 80,451\end{array}$ & $\begin{array}{c}\text { above } \\
\$ 80,451\end{array}$ \\
\hline \multirow[t]{8}{*}{ Aboriginal } & Canada (urban areas) & $34.4 \%$ & $32.7 \%$ & $32.9 \% *$ \\
\hline & None & $29.8 \% *$ & $32.5 \%$ & $37.7 \%$ * \\
\hline & One & $32.9 \%{ }^{*}$ & $32.7 \%$ & $34.5 \% *$ \\
\hline & Two & $35.8 \%{ }^{*}$ & $32.4 \%$ & $31.8 \% *$ \\
\hline & Three & $35.8 \% *$ & $33.9 \%{ }^{*}$ & $30.3 \% *$ \\
\hline & Four & $39.8 \% *$ & $32.2 \%$ & $28.0 \%$ * \\
\hline & Five & $42.5 \% *$ & $33.6 \% *$ & $23.9 \%$ * \\
\hline & Six or more & $47.9 \%{ }^{*}$ & $34.3 \%{ }^{*}$ & $17.8 \%$ * \\
\hline
\end{tabular}

* Statistically significant difference between specific number of times moved in the past five years and total population in urban areas of Canada in that income group, (excluding First Nations onreserve), $\mathrm{p}<0.01$, Z-test of two population proportions 


\section{Aboriginal and non-Aboriginal Income by Education}

Household income by education levels was examined for all Aboriginal households, for First Nations compared to other Aboriginal households, and for Aboriginal households compared to non-Aboriginal households.

Looking at Table 7, urban Aboriginal university graduates were most likely to be in the higher household-income category compared to all Aboriginal people across Canada. There were no notable differences by education for urban Aboriginal people in the middleincome category. There were lower proportions of urban Aboriginal people with postsecondary education in the lower household-income category and higher proportions of urban Aboriginal people with some high school or less in the lower-income category.

There were smaller proportions of First Nations compared to other Aboriginal people in the high-income category, regardless of education level. There were smaller proportions of First Nations who had some high school in the middle household-income category, and greater proportions of First Nations who had completed university in the middle household-income category. There were larger proportions of First Nations than other Aboriginal people in the lower-income category in every education category other than the university graduates.

Finally, comparing Aboriginal and non-Aboriginal people, there were smaller proportions of Aboriginal people with high income compared to non-Aboriginal people across all education categories. There were similar proportions of Aboriginal than nonAboriginal people in the middle-income category. There were higher proportions of Aboriginal than non-Aboriginal people in the lower-income category other than for university graduates, where proportions were not notably different.

These results suggest that education links well to income among Aboriginal people. However, First Nations have lower incomes generally, in comparison to other Aboriginal people. Further, Aboriginal people are more likely to have lower incomes and less likely to have higher incomes than non-Aboriginal people across education levels. However, the proportion of Aboriginal and non-Aboriginal people in the middle-income category was similar across all education levels, other than the lowest education level. 
Table 7: Urban Aboriginal Household Income (First Nations, other Aboriginal and total Aboriginal People) by Education (percent)

\begin{tabular}{|c|c|c|c|c|}
\hline \multirow[b]{2}{*}{ Population } & \multirow[b]{2}{*}{$\begin{array}{l}\text { Highest education level } \\
\text { completed }\end{array}$} & $\begin{array}{l}\text { Low } \\
\text { Income }\end{array}$ & $\begin{array}{l}\text { Middle- } \\
\text { income }\end{array}$ & $\begin{array}{c}\text { High } \\
\text { Income }\end{array}$ \\
\hline & & $\begin{array}{c}\text { Less } \\
\text { than } \\
\$ 40,226\end{array}$ & $\begin{array}{c}\$ 40,226 \\
\text { to } \\
\$ 80,451\end{array}$ & $\begin{array}{l}\text { Above } \\
\$ 80,451\end{array}$ \\
\hline \multirow{6}{*}{$\begin{array}{l}\text { First Nations } \\
\text { Off-Reserve }\end{array}$} & Canada (urban areas) & $42.5 \%{ }^{\dagger}$ & $32.4 \%^{t}$ & $25.1 \%^{\dagger}$ \\
\hline & Elementary or less & $100.0 \%{ }^{*}$ & $0.0 \%{ }^{*}$ & $0.0 \%{ }^{*}$ \\
\hline & Some high school & $53.1 \%{ }^{*}+$ & $28.7 \%{ }^{*}+$ & $18.2 \%{ }^{*} \dagger$ \\
\hline & Completed high school & $42.5 \%{ }^{\dagger}$ & $33.0 \%{ }^{*}$ & $24.5 \%{ }^{*}+$ \\
\hline & $\begin{array}{l}\text { Completed post-secondary } \\
\text { non-university }\end{array}$ & $36.0 \%{ }^{*} t$ & $35.3 \%{ }^{*}+$ & $28.7 \%{ }^{*}+$ \\
\hline & Completed university & $23.5 \%{ }^{*} \dagger$ & $36.0 \%{ }^{*} t$ & $40.5 \%{ }^{*}{ }^{\dagger}$ \\
\hline \multirow{6}{*}{ Other Aboriginal } & Canada (urban areas) & $30.6 \%{ }^{\dagger}$ & $34.3 \%^{t}$ & $35.1 \%^{\dagger}$ \\
\hline & Elementary or less & $100.0 \%{ }^{*}$ & $0.0 \%{ }^{*}$ & $0.0 \%{ }^{*}$ \\
\hline & Some high school & $38.6 \%{ }^{*} t$ & $35.1 \%{ }^{*} t$ & $26.3 \%{ }^{*} \dagger$ \\
\hline & Completed high school & $31.9 \%{ }^{*} t$ & $33.5 \%{ }^{*}$ & $34.6 \%{ }^{*}+$ \\
\hline & $\begin{array}{l}\text { Completed post-secondary } \\
\text { non-university }\end{array}$ & $27.9 \%{ }^{*}+$ & $36.6 \%{ }^{*} t$ & $35.5 \%{ }^{*}+$ \\
\hline & Completed university & $20.8 \%{ }^{*} t$ & $30.5 \%{ }^{*} t$ & $48.7 \%{ }^{*} \dagger$ \\
\hline \multirow{6}{*}{ Total Aboriginal } & Canada (urban areas) & $35.0 \%$ & $33.6 \%$ & $31.4 \%$ \\
\hline & Elementary or less & $100.0 \%{ }^{*}$ & $0.0 \%{ }^{*}$ & $0.0 \%{ }^{*}$ \\
\hline & Some high school & $45.1 \%{ }^{*}$ & $32.2 \%{ }^{*}$ & $22.7 \%^{*}$ \\
\hline & Completed high school & $35.8 \%{ }^{*}$ & $33.3 \%$ & $30.9 \%{ }^{*}$ \\
\hline & $\begin{array}{l}\text { Completed post-secondary } \\
\text { non-university }\end{array}$ & $30.7 \%{ }^{*}$ & $36.2 \%{ }^{*}$ & $33.2 \%{ }^{*}$ \\
\hline & Completed university & $21.5 \%{ }^{*}$ & $32.0 \%{ }^{*}$ & $46.5 \%{ }^{*}$ \\
\hline \multirow{5}{*}{ Non-Aboriginal } & Canada (urban areas) & $27.0 \%^{n}$ & $33.3 \%^{n}$ & $39.7 \%^{n}$ \\
\hline & $\begin{array}{l}\text { Elementary or less \& some } \\
\text { high school* }\end{array}$ & $39.5 \%^{n}$ & $33.2 \%^{n}$ & $27.4 \%^{n}$ \\
\hline & Completed high school & $26.9 \%^{n}$ & $34.5 \%^{n}$ & $38.6 \%{ }^{n}$ \\
\hline & $\begin{array}{l}\text { Completed post-secondary } \\
\text { non-university }\end{array}$ & $24.6 \%{ }^{n}$ & $36.4 \%$ & $39.0 \%{ }^{n}$ \\
\hline & Completed university & $17.4 \%^{n}$ & $27.4 \%^{n}$ & $55.2 \%^{n}$ \\
\hline
\end{tabular}

* Statistically significant difference between specific education level completed and total population in urban areas of Canada, (excluding First Nations on-reserve), $p<0.01$, Z-test of two population proportions

$\dagger$ Statistically significant difference between First Nations off-reserve and other Aboriginal people within the same highest education level completed, $\mathrm{p}<0.01$, Z-test of two population proportions $\mathrm{n}$ Statistically significant difference between total Aboriginal and non-Aboriginal people within the same highest education level completed, $\mathrm{p}<0.01$, Z-test of two population proportions 


\section{Aboriginal and non-Aboriginal Income by Employment Status}

We examined the employment status of urban Aboriginal people by low, middle, and high-income household status. The data was provided in three categories: essentially, those who were employed or temporarily absent from their job; those who were unemployed and either looking for work; and those who were unemployed but not looking for work. We began the analysis by examining all urban Aboriginal people, then looking at First Nations and other Aboriginal people and, finally, by comparing the income of all urban Aboriginal people to non-Aboriginal people by their employment status.

Not surprisingly, there were higher proportions of urban Aboriginal people working or temporarily absent from a high-income job than of those who were unemployed (see Table 8). There were notably lower proportions of urban Aboriginal people in the middle-income category who were unemployed and not looking for employment compared to urban Aboriginal people who were working or temporarily absent from a job. There were smaller proportions of urban Aboriginal people who were employed in the low-income category and greater proportions that were unemployed in the low-income category, regardless of the reason for unemployment.

Fewer First Nations were in the high-income category regardless of employment status compared to other Aboriginal people, and fewer unemployed First Nations were in the middle-income category compared to other Aboriginal people. More First Nations were in the low-income category, regardless of employment status, when compared to other Aboriginal people.

Aboriginal people were less likely than non-Aboriginal people to have high income and more likely than non-Aboriginal people to be in the low-income category, regardless of employment status. However there were no notable differences between the two groups in the middle-income category.

Results indicate that employment and income are strongly linked for Aboriginal and non-Aboriginal people. However, Aboriginal people are more likely to have lower incomes in comparison to non-Aboriginal people, and other Aboriginal people are more likely than First Nations to have higher income regardless of employment status. 
TABLE 8: Urban Aboriginal (First Nations, other Aboriginal and total Aboriginal people) and non-Aboriginal Household Income by Employment (percent)

\begin{tabular}{|c|c|c|c|c|}
\hline \multirow[b]{2}{*}{ Population } & \multirow[b]{2}{*}{ Employment Status } & $\begin{array}{c}\text { Low } \\
\text { Income }\end{array}$ & $\begin{array}{l}\text { Middle- } \\
\text { income }\end{array}$ & $\begin{array}{c}\text { High } \\
\text { Income }\end{array}$ \\
\hline & & $\begin{array}{l}\text { Less than } \\
\$ 40,226\end{array}$ & $\begin{array}{c}\$ 40,226 \\
\text { to } \\
\$ 80,451\end{array}$ & $\begin{array}{l}\text { above } \\
\$ 80,451\end{array}$ \\
\hline \multirow{4}{*}{$\begin{array}{l}\text { First Nations } \\
\text { Off-Reserve }\end{array}$} & Canada (urban areas) & $42.7 \%^{\dagger}$ & $32.2 \%{ }^{\dagger}$ & $25.1 \%{ }^{\dagger}$ \\
\hline & $\begin{array}{l}\text { Worked for pay or in self-emp., } \\
\text { or temporarily absent from job }\end{array}$ & $31.9 \%{ }^{*} t$ & $36.3 \%{ }^{*} t$ & $31.9 \%{ }^{*} t$ \\
\hline & $\begin{array}{l}\text { Respondent does not have job, } \\
\text { is looking for work }\end{array}$ & $54.5 \%{ }^{*}+$ & $26.9 \%{ }^{*} t$ & $18.6 \%{ }^{*} t$ \\
\hline & $\begin{array}{l}\text { Respondent does not have job, } \\
\text { is not looking for work }\end{array}$ & $59.4 \%{ }^{*} t$ & $26.3 \%{ }^{*} t$ & $14.3 \%{ }^{*}+$ \\
\hline \multirow{4}{*}{$\begin{array}{l}\text { Other } \\
\text { Aboriginal }\end{array}$} & Canada (urban areas) & $30.6 \%^{\dagger}$ & $34.3 \%^{\dagger}$ & $35.1 \%^{\dagger}$ \\
\hline & $\begin{array}{l}\text { Worked for pay or in self-emp., } \\
\text { or temporarily absent from job }\end{array}$ & $24.6 \%{ }^{*}+$ & $35.7 \%{ }^{*}+$ & $39.7 \%{ }^{*}+$ \\
\hline & $\begin{array}{l}\text { Respondent does not have job, } \\
\text { is looking for work }\end{array}$ & $37.6 \%{ }^{*}+$ & $33.3 \%{ }^{*} t$ & $29.1 \%{ }^{*}+$ \\
\hline & $\begin{array}{l}\text { Respondent does not have job, } \\
\text { is not looking for work }\end{array}$ & $46.2 \%{ }^{*}+$ & $30.3 \%{ }^{*} t$ & $23.5 \%{ }^{*} t$ \\
\hline \multirow{4}{*}{$\begin{array}{l}\text { Total } \\
\text { Aboriginal }\end{array}$} & Canada (urban areas) & $35.1 \%$ & $33.5 \%$ & $31.4 \%$ \\
\hline & $\begin{array}{l}\text { Worked for pay or in self-emp., } \\
\text { or temporarily absent from job }\end{array}$ & $27.1 \%{ }^{*}$ & $35.9 \%{ }^{*}$ & $37.0 \%{ }^{*}$ \\
\hline & $\begin{array}{l}\text { Respondent does not have job, } \\
\text { is looking for work }\end{array}$ & $45.5 \%{ }^{*}$ & $30.3 \%{ }^{*}$ & $24.2 \%{ }^{*}$ \\
\hline & $\begin{array}{l}\text { Respondent does not have job, } \\
\text { is not looking for work }\end{array}$ & $51.9 \%{ }^{*}$ & $28.6 \%{ }^{*}$ & $19.5 \%{ }^{*}$ \\
\hline \multirow{4}{*}{$\begin{array}{l}\text { Non- } \\
\text { Aboriginal }\end{array}$} & Canada (urban areas) & $27.0 \%^{n}$ & $33.3 \%^{n}$ & $39.7 \%^{n}$ \\
\hline & $\begin{array}{l}\text { Worked for pay or in self-emp., } \\
\text { or temporarily absent from job }\end{array}$ & $18.5 \%^{n}$ & $33.8 \%{ }^{n}$ & $47.7 \%^{n}$ \\
\hline & $\begin{array}{l}\text { Respondent does not have job, } \\
\text { is looking for work }\end{array}$ & $37.1 \%^{n}$ & $31.2 \%^{n}$ & $31.7 \%^{n}$ \\
\hline & $\begin{array}{l}\text { Respondent does not have job, } \\
\text { is not looking for work }\end{array}$ & $42.1 \%^{n}$ & $32.6 \%{ }^{n}$ & $25.4 \%^{n}$ \\
\hline
\end{tabular}

* Statistically significant difference between specific language group and total population in urban areas of Canada (excluding First Nations on-reserve), $\mathrm{p}<0.01$, Z-test of two population proportions

$\dagger$ Statistically significant difference between First Nations off-reserve and other Aboriginal people within the same language, $\mathrm{p}<0.01$, Z-test of two population proportions

$\mathrm{n}$ Statistically significant difference between total Aboriginal and non-Aboriginal people within the same language group, $\mathrm{p}<0.01, \mathrm{Z}$-test of two population proportions 


\section{Aboriginal and non-Aboriginal Income by Language}

We examined income by language in two ways: first, looking generally at whether urban Aboriginal people and non-Aboriginal people selected English, French, both English and French, or neither English and French as their official language; and, secondly, by looking at the proportion of urban Aboriginal people who could speak or understand an Aboriginal language.

Urban Aboriginal people who spoke only French were less likely to be in the highincome category and more likely to be in the middle-income category, as seen in Table 9. There were lower proportions of bilingual urban Aboriginal people in the low-income category.

As with other factors examined in this article, there were lower proportions of First Nations than other Aboriginal people in the high-income category regardless of official language. In the middle-income category there were no notable differences. More First Nations than other Aboriginal people were in the low-income category if they spoke solely English or French.

When comparing urban Aboriginal and non-Aboriginal people in the high-income category, results showed there were fewer Aboriginal people who spoke English or French alone in the high-income category as compared to non-Aboriginal people, while there were more Aboriginal than non-Aboriginal people in the high-income category who were bilingual. While there were no notable differences in the middle-income category, there were more Aboriginal than non-Aboriginal people who spoke only English or French in the low-income category, but fewer bilingual Aboriginal than non-Aboriginal people in the low-income category.

Taken together, these results suggested that bilingualism was a great asset for Aboriginal people with regards to income.

Table 10 outlines the income data describing the ability of urban Aboriginal people across Canada to speak and understand, understand only, or to neither speak nor understand an Aboriginal language. While there were no notable differences between urban Aboriginal people in middle-income households according to the ability to speak and understand an Aboriginal language, there were clearly fewer urban Aboriginal people who could speak and understand an Aboriginal language in high-income households and greater proportions of urban Aboriginal people who could speak and understand an Aboriginal language in lowincome households. 
TABLE 9: Urban Aboriginal Household Income (First Nations, other Aboriginal and total Aboriginal People) by Official Language (percent)

\begin{tabular}{|c|c|c|c|c|}
\hline \multirow[b]{2}{*}{ Population } & \multirow[b]{2}{*}{ Language } & $\begin{array}{c}\text { Low } \\
\text { Income }\end{array}$ & $\begin{array}{l}\text { Middle- } \\
\text { income }\end{array}$ & $\begin{array}{c}\text { High } \\
\text { Income }\end{array}$ \\
\hline & & $\begin{array}{l}\text { Less than } \\
\$ 40,226\end{array}$ & $\begin{array}{c}\$ 40,226 \\
\text { to } \\
\$ 80,451\end{array}$ & $\begin{array}{c}\text { above } \\
\$ 80,451\end{array}$ \\
\hline \multirow{5}{*}{$\begin{array}{l}\text { First Nations } \\
\text { Off-Reserve }\end{array}$} & Canada (urban areas) & $42.6 \%^{\dagger}$ & $32.4 \%{ }^{\dagger}$ & $25.1 \%^{\dagger}$ \\
\hline & English only & $43.8 \%{ }^{*} t$ & $31.5 \%{ }^{*} t$ & $24.6 \%{ }^{*} t$ \\
\hline & French only & $47.9 \%{ }^{*} t$ & $34.8 \%{ }^{*} t$ & $17.4 \%{ }^{*}+$ \\
\hline & Both English and French & $32.0 \%{ }^{*} t$ & $37.1 \%{ }^{*} t$ & $30.9 \%{ }^{*}+$ \\
\hline & Neither English nor French & $\mathrm{N} / \mathrm{A}$ & $\mathrm{N} / \mathrm{A}$ & $\mathrm{N} / \mathrm{A}$ \\
\hline \multirow{5}{*}{ Other Aboriginal } & Canada (urban areas) & $30.7 \%^{\dagger}$ & $34.3 \%^{\dagger}$ & $35.0 \%^{\dagger}$ \\
\hline & English only & $30.6 \%^{\dagger}$ & $33.4 \%{ }^{*} t$ & $36.0 \%{ }^{*}+$ \\
\hline & French only & $34.3 \%{ }^{*} t$ & $39.1 \%{ }^{*} t$ & $26.6 \%{ }^{*} \dagger$ \\
\hline & Both English and French & $29.7 \%{ }^{*} \dagger$ & $34.8 \%{ }^{*} t$ & $35.5 \%{ }^{*}+$ \\
\hline & Neither English nor French & $\mathrm{N} / \mathrm{A}$ & N/A & $\mathrm{N} / \mathrm{A}$ \\
\hline \multirow{5}{*}{ Total Aboriginal } & Canada (urban areas) & $35.1 \%$ & $33.6 \%$ & $31.3 \%$ \\
\hline & English only & $36.3 \%{ }^{*}$ & $32.6 \%{ }^{*}$ & $31.1 \%{ }^{*}$ \\
\hline & French only & $37.4 \%{ }^{*}$ & $38.1 \%{ }^{*}$ & $24.5 \%{ }^{*}$ \\
\hline & Both English and French & $30.2 \%{ }^{*}$ & $35.3 \%{ }^{*}$ & $34.5 \%{ }^{*}$ \\
\hline & Neither English nor French & $\mathrm{N} / \mathrm{A}$ & $\mathrm{N} / \mathrm{A}$ & $\mathrm{N} / \mathrm{A}$ \\
\hline \multirow{5}{*}{ Non-Aboriginal } & Canada (urban areas) & $26.3 \%^{n}$ & $33.5 \%$ & $40.2 \%^{n}$ \\
\hline & English only & $24.4 \%^{n}$ & $32.8 \%^{n}$ & $42.8 \%^{n}$ \\
\hline & French only & $30.7 \%^{n}$ & $36.1 \%^{n}$ & $33.2 \%^{n}$ \\
\hline & Both English and French & $35.3 \%^{n}$ & $35.7 \%^{n}$ & $29.0 \%^{n}$ \\
\hline & Neither English nor French & $40.5 \%$ & $31.6 \%$ & $27.9 \%$ \\
\hline
\end{tabular}

* Statistically significant difference between specific language group and total population in urban areas of Canada (excluding First Nations on-reserve), $\mathrm{p}<0.01$, Z-test of two population proportions

$\dagger$ Statistically significant difference between First Nations off-reserve and other Aboriginal people within the same language, $\mathrm{p}<0.01$, Z-test of two population proportions

$\mathrm{n}$ Statistically significant difference between total Aboriginal and non-Aboriginal people within the same language group, $\mathrm{p}<0.01$, Z-test of two population proportions 
TABLE 10: Urban Aboriginal Household Income by Aboriginal Language (percent)

\begin{tabular}{|l|l|c|c|c|}
\hline \multirow{5}{*}{ Population } & $\begin{array}{c}\text { Ability to speak an } \\
\text { Aboriginal Language }\end{array}$ & $\begin{array}{c}\text { Low } \\
\text { Income }\end{array}$ & $\begin{array}{c}\text { Middle- } \\
\text { income }\end{array}$ & $\begin{array}{c}\text { High } \\
\text { Income }\end{array}$ \\
\cline { 3 - 5 } & $\begin{array}{c}\text { Less than } \\
\mathbf{\$ 4 0 , 2 2 6}\end{array}$ & $\begin{array}{c}\mathbf{\$ 4 0 , 2 2 6} \text { to } \\
\mathbf{\$ 8 0 , 4 5 1}\end{array}$ & $\begin{array}{c}\text { above } \\
\mathbf{\$ 8 0 , 4 5 1}\end{array}$ \\
\hline \multirow{3}{*}{ Aboriginal } & Canada (urban areas) & $\mathbf{3 4 . 9 \%}$ & $\mathbf{3 3 . 6 \%}$ & $\mathbf{3 1 . 5 \%}$ \\
\cline { 2 - 5 } & Speak and understand & $51.3 \%^{*}$ & $29.1 \%^{*}$ & $19.6 \%{ }^{*}$ \\
\cline { 2 - 5 } & Understand only & $38.4 \%^{*}$ & $33.2 \%^{*}$ & $28.4 \%^{*}$ \\
\cline { 2 - 5 } & Neither speak nor understand & $31.0 \%^{*}$ & $34.6 \%^{*}$ & $34.4 \%^{*}$ \\
\hline
\end{tabular}

* Statistically significant difference between specific Aboriginal language group and total Aboriginal population in urban areas of Canada (excluding First Nations on-reserve), $p<0.01$, Z-test of two population proportions

\section{Discussion}

It does seem that there is a definite urban Aboriginal middle-income group in Canada that is similar in many ways to the non-Aboriginal middle-income group. The very fact that there were fewer differences at the middle-income level between these two groups suggests that Aboriginal people in this income bracket are doing as well as non-Aboriginal people, at least when comparing the factors captured in the Census and the APS surveys. Whether or not this is a signal that more Aboriginal people are moving from lower to higher incomes through the middle-income category, though, will not be known without a longitudinal analysis. What we do know is that differences between urban Aboriginal and non-Aboriginal people in Canada were more often found at the income extremes, generally with more Aboriginal people in the low-income category and fewer in the higher income category. This is a long-standing pattern, and does not come as a surprise (Heisz 2007).

It was perhaps not surprising to see higher proportions of Aboriginal household incomes in the high-income category in the Northwest Territories and Alberta, given their economies. The lower proportions in the Yukon and in Saskatchewan were more surprising. This suggests that while the economies of the latter jurisdictions are doing well, that Aboriginal people are still being left out of the growth, either due to insufficient skills development, discrimination, or other factors.

Ottawa-Gatineau and Toronto were the CMAs with the wealthiest Aboriginal households. In Ottawa-Gatineau, this would likely be due to the large proportion of federal government employees in this area. Federal departments have higher salaries in many areas when compared to the private sector, which would contribute to higher incomes for Aboriginal people. The finding that Aboriginal people have higher incomes when they are bilingual would make sense here, as the federal government also has a bilingualism policy.

Not surprisingly, Aboriginal people who are in the workforce were most likely to be in either the middle or the high-income categories compared to those not in the workforce, similar to the case for non-Aboriginal people. The proportion in the middle-income group was similar between Aboriginal persons and non-Aboriginal persons in the workforce, 
although there was still a gap in terms of the proportion of working people in the upperincome group. Clearly there are factors beyond participation in the workforce contributing to income disparity, though this data does not address quality or level of employment.

Overall, for many of the factors that were examined, Aboriginal people are not doing as well as non-Aboriginal people. There are variations in the pattern but, outside of the middle-income category, Aboriginal people are more likely to be in the lower-income category and less likely to be in the higher-income category. Language is the one variable where the pattern is completely different; being bilingual was a distinct advantage for Aboriginal people only, while being unilingual English was an advantage for nonAboriginal people only. Another interesting finding was that Aboriginal people who spoke an Aboriginal language were less likely to be in the higher-income categories. This can imply that Aboriginal people who are less connected to their culture are more likely to succeed in the broader Canadian culture. In fact, this implication is borne out in Kuhn and Sweetman (2002), where the authors found that (ancestral or current) intermarriage with non-Aboriginal people was one factor that had a significant positive impact on wages and employment rates for Aboriginal people. It could also be that older and younger Aboriginal people are more likely to hold a closer cultural connection than middle-age Aboriginal groups, but these people are also coincidentally in the least wealthy age groups. Our article does not contain an analysis of the interaction between age and language in relation to income, preventing a better understanding of this relationship.

Looking within the group of Aboriginal people, a striking finding was that, quite often, the First Nations group had lower income levels than other Aboriginal people. This difference was consistent even at higher education levels and has been borne out in other research that controlled for other factors (Pendakur and Pendakur 2011). This suggests that there are systemic factors at work among First Nations, which have an impact upon the economic place of First Nations within Canadian society that go well beyond an ability to gain an education and, subsequently, earn an income. While one can postulate that these might be the social, psychological, and emotional effects of colonization, residential schooling, and cultural adjustment that First Nations deal with far more often than do other Aboriginal people, this is but one hypothesis that would need to be examined. Analysis of the Census and the APS is simply not a good approach to test this hypothesis, as these questionnaires have limited items on the issues of residential schooling. Further qualitative analysis would, perhaps, be more useful here. Furthermore, these findings suggest that the types of supports that need to be provided, for First Nations in particular, should go beyond making education more accessible, and also focus on helping First Nations people in particular to overcome other, less obvious barriers.

\section{Conclusion}

Overall, there were similar patterns throughout the data where Aboriginal people tended to be more often in lower-income categories and less often in high-income categories than non-Aboriginal people. This is a finding that has been repeated in the research for some time now, suggesting that the issues that have had an impact upon Aboriginal people and their success are not yet resolved. 
Positively, however, while there are still clear income disparities between Aboriginal and non-Aboriginal people and between First Nations and other Aboriginal people, the research on the burgeoning urban Aboriginal middle-income group is supported in this article. The issue is how Aboriginal people can be supported to grow further and to move into the middle and higher income groups, and whether or not this trend will continue in the current economic climate. While education and training are part of the answer, other factors are at play. ${ }^{5}$ This relationship between education/training and income for Aboriginal people must be better understood and more approaches must be considered if Aboriginal people are to participate fully in economic growth and development in Canada.

While this data was broken into data for First Nations and other Aboriginal people, much of the data that provided the context for this research was not provided at a granular level. It would be helpful for future research to use data collected at a granular level, to allow for greater understanding of the Aboriginal population and the groups of First Nations, Métis, and Inuit who make up this population. Future research should also address biases that lead to overestimates of income among Aboriginal people.

5 While Pendakur and Pendakur (2011) have found a large income disparity between Aboriginal and nonAboriginal people, even when Aboriginal people have high levels of education, other research has shown that education and training is a critical part of higher income earnings for Aboriginal people. In fact, Sharpe and Arsenault $(2010, \mathrm{v})$ say that "Education is by far the most important determinant of labour market outcomes and also plays a pre-eminent role in improving social outcomes." For this reason and the data from this study, we see a clear link between education and training and increased income. 


\section{Bibliography}

Aboriginal Peoples Survey (APS). n.d. Accessed 3 March 2012. http://www.statcan.gc.ca/ cgi-in/imdb/p2SV.pl?Function=getSurvey\&SDDS=3250\&lang=en \&db=imdb\&ad $\mathrm{m}=8$ \&dis $=2$

Adams, C. 2009. "Voice of Manitoba's Aboriginal Peoples: Links to Perceptions on Health, Economic Outlook and Mobility." Canadian Diversity 7 (3): 69-76.

Bopp, M., J. Bopp, and P. Lane Jr. 2003. Aboriginal Domestic Violence in Canada. Aboriginal Healing Foundation Research Series. Accessed 9 December 2012. http://www.fourworlds.ca/pdfs/DomesticViolence.pdf

Brzozowski, J.-A., A. Taylor-Butts, and S. Johnson. 2006. June. Victimization and Offending Among the Aboriginal Population in Canada. Juristat, Canadian Centre for Justice Statistics, Statistics Canada Catalogue N0.85-002-XIE, vol. 26, no. 3 (June). Accessed 29 September 2011. http://www.statcan.gc.ca/pub/85-002-x/85002-x2006003-eng.pdf.

Canada Mortgage and Housing Corporation. 2008. Neighborhood Effects and Concentration Levels of Aboriginal People in Large Canadian Cities. Accessed 25 April 2012. http://www.cmhc-schl.gc.ca/odpub/pdf/65674. pdf?fr $=1359319568703$

Clatworthy, S. 2000. First Nation Affiliation Among Registered Indians Residing in Select Urban Areas. Accessed 2 March 2012. http://www.aadnc-aandc. gc.ca/DAM/DAM-INTER-HQ/STAGING/texte-text/rs_pubs_re_aar_ aar_1317307814611_eng.pdf

Environics Institute. 2010. Urban Aboriginal Peoples Study Main Report. Toronto: Environics Institute.

Guimond, E. 2003. "Fuzzy definitions and population explosions: Changing identities of Aborigial groups in Canada." In Not Strangers in These Parts: Urban Aboriginal Peoples, ed. D. Newhouse and E. Peters, 35-50. Ottawa: Policy Research Initiative.

Guimond, E., N. Robitaille, and S. Senecal. 2009. "Aboriginal People in Canadian Cities: Why are They Growing so Fast?” Canadian Issues (Winter): 11-17.

Harlow, L. L. 2005. The Essence of Multivariate Thinking: Basic Themes and Methods. Mahwah, NJ: Lawrence Erlbaum Associates Inc.

Hays, W. 1994. Statistics. Orlando, FL: Harcourt Brace and Company.

Heisz, A. 2007. Income Inequality and Redistribution in Canada: 1976 to 2004. Accessed 10 January 2012. http://www.statcan.gc.ca/ pub/11f0019m/11f0019m2007298-eng.pdf

Ipsos-Reid. 2006. Aboriginal Women and Family Violence. Ottawa: Indian and Northern Affairs. 
Kuhn, P., and A. Sweetman. 2002. "Aboriginals as unwilling immigrants: Contact, assimilation and labour market outcomes." Journal of Population Economics 15 (2): 331-55. http://dx.doi.org/10.1007/s001480100083

Ministry of Aboriginal Affairs. n.d. Ministry of Aboriginal Affairs Quick Facts First Nations in Ontario. Accessed 3 March 2012. http://www.aboriginalaffairs.gov. on.ca/english/services/datasheets/first_nations.asp

National Association of Friendship Centres. n.d. Urban Aboriginal Women: Social Determinants of Health and Well-Being. Accessed 25 April 2012. http://www.laa. gov.nl.ca/laa/naws/pdf/NAFC-UrbanAboriginalWomen.pdf

Norris, M. J. 2006. “Aboriginal Languages in Canada: Trends and Perspectives on Maintainance and Revitalization." In Aboriginal Policy Research: Moving Forward, Making a Difference, vol. 3, ed. J.P. White, S. Wingert, D. Beavon, and P. Maxim, 197-226. Toronto: Thompson Educational Publishing, Inc.

Norris, M. J., and S. Clatworthy. 2003. "Aboriginal Mobility and Migration Within Urban Canada: Outcomes, Factors and Implications." In Not Strangers in These Parts: Urban Aboriginal Peoples, ed. D. Newhouse and E. Peters, 51-78. Ottawa: Policy Research Initiative.

_. 2011. "Urbanization and Migration Patterns of Aboriginal Populations in Canada: A Half Century in Review (1951 to 2006)." aboriginal policy studies 1 (1): 13-77. http://dx.doi.org/10.5663/aps.v1i1.8970

Ontario Trillium Foundation. 2011. Aboriginal Communities in Profile. Accessed 24 April 2012. http://www.trilliumfoundation.org/en/knowledgeSharingCentre/ resources/Aboriginal_Profile_Ontario.pdf

Pagano, R.R. 2010. Understanding Statistics in the Behavioral Sciences. Belmont, CA: Wadsworth.

Pendakur, P., and R. Pendakur. 2011. "Aboriginal income disparity in Canada.” Canadian Public Policy 37 (1): 61-83. http://dx.doi.org/10.3138/cpp.37.1.61

Sharpe, A., and J.-F. Arsenault. 2010. Investing in Aboriginal Education in Canada: An Economic Perspective. Ottawa: Centre for the Study of Living Standards.

Smylie, J., M. Firestone, L. Cochran, C. Prince, S. Maracle, M. Morley, et al. 2011. Our Health Counts: Urban Aboriginal Health Database Research Project Community Report First Nations Adults and Children. Accessed 3 February 2012. http:// www.stmichaelshospital.com/pdf/crich/our-health-counts-report.pdf

Statistics Canada. 2007. How Statistics Canada Identifies Aboriginal Peoples. Catalogue Number 12-592-XIE. . 2008. Aboriginal Peoples in Canada in 2006: Inuit, Metis and First Nations, 2006 Census. Accessed 16 January 2012. http://www12.statcan.ca/censusrecensement/2006/as-sa/97-558/pdf/97-558-XIE2006001.pdf 
- 2010. Aboriginal Statistics at a Glance. Accessed 4 March 2012. http://www. statcan.gc.ca/pub/89-645-x/2010001/income-revenu-eng.htm.

Urban Aboriginal Task Force. 2007. Urban Aboriginal Task Force Final Report. The Ontario Federation of Indian Friendship Centres, The Ontario Metis Aboriginal Association, The Ontario Native Women's Association.

Wilson, D., and D. Macdonald. 2010. The Income Gap Between Aboriginal Peoples and the Rest of Canada. Accessed 15 January 2012. http://www.policyalternatives.ca/ sites/default/files/uploads/publications/reports/docs/Aboriginal percent20Income percent20Gap.pdf 